Research Articles

\title{
Synergistic Potential of the Leaves of Aspillia Africana (Compositae) and Psidium guajava (Myrtaceae) Against Some Selected Bacterial and Fungal Isolates
}

\author{
F. A. Ologundudu*, S. O. Idris ${ }^{1}$ \\ *Plant physiology and Biochemistry unit, Department of Biology, Federal University of Technology, \\ Akure, Nigeria. \\ ${ }^{1}$ Department of Science Laboratory Technology, Federal Polytechnic Ede, Osun State, Nigeria.
}

\section{Article Info}

History

Received: 20 Nov 2019

Accepted: 8 Jul 2020

Available: 31 Aug 2020

\begin{abstract}
Background: The plethora of secondary metabolites inherent in plants that could be synthesized and formulated into useful drugs for the treatment of diseases is not fully understood.

Objectives: This research was carried out to investigate the antimicrobial potential of the leaves of Aspillia africana and Psidium guajava plants on some selected bacterial and fungal isolates.

Methods: Fresh and matured leaves of Aspillia africana and Psidium guajava were collected at the Federal College of Agriculture, Akure and the Botanical Garden, Obafemi Awolowo University (OAU), Ile-Ife, Nigeria. The plants were identified and voucher specimen deposited at IFE Herbarium. The pure isolates of the bacteria and fungi were obtained from Medical Microbiology unit, Department of Microbiology, Obafemi Awolowo University, Ile-Ife, Nigeria. The bacteria isolates were maintained on nutrient agar and the fungal isolates on Sabouraud Dextrose Agar (SDA). Extraction of the plant materials using methanol, ethanol and aqueous fractions were carried out using standard protocols. The isolates were inoculated on a nutrient broth. The Minimum Inhibitory Concentration (MIC) of the extracts was determined by broth dilution method while minimal bactericidal and fungicidal concentrations respectively were determined following established protocols.

Results and conclusion: The results showed that Bacillus cereus, Cornybacterium pyogenes, Klebsiella pneumonia and Escherichia coli showed higher degree of resistance to the plant extracts. The fungal isolates; Candida albicans, Tryptophyton rubrum, Penicillium expansium, and Aspergillus flavus were resistant to Psidium guajava extract as no significant biological activity was observed. All the extracts from the plants produced considerable antimicrobial activities with Streptococcus faecalis and Staphyloccocus. aureus. whereas, these organisms were resistant to ofloxacin, sparfloxacin, chloramphenicol, augmentin, ciprofloxacin and septrin. This study concludes that ethanolic extracts $(100 \mathrm{mg} / \mathrm{ml})$ of the leaf of Aspillia africana is more potent than the methanolic and aqueous extracts of Psidium guajava. This study demonstrated that the therapeutic properties of Aspillia africana and Psidium guajava are better enhanced with their synergistic potential to the tested microorganisms.
\end{abstract}

Keywords: Aspillia Africana, Bactericidal, Psidium guajava, Synergistic, therapeutic Permalink/ DOI: https://doi.org/10.14710/jbtr.v6i2.6417

\section{INTRODUCTION}

Crude extracts of medicinal plants notwithstanding stand out as veritable sources of potential resistance agents and the African biosphere promises to be a potential source of such compounds owing to its rich plant species diversity ${ }^{1 .}$ According to World Health Organization $^{2}$, a larger percentage of the world's population is based mainly on traditional medicine and a significant part of the therapy involves the use of plant materials or their bioactive components. There are many 
findings on the therapeutic potentials of plant extracts against bacteria $^{3}$, hence, plants are still being recognized as the pivot of modern medicine for the prophylaxis of infectious diseases ${ }^{4}$. Therefore, the contributions of bites. The plant is widely used as haemostatic agent (spontaneous arrest of bleeding from damaged blood vessels). The fresh leaves are effective in wound healing, cuts and sores 9 .

Table 1. Antimicrobial effect of methanolic (M), Ethanolic (E) and Aqueous (A) extracts of Aspillia africana and Psidium guajava on some selected bacterial and fungal isolates

\begin{tabular}{|c|c|c|c|c|c|c|}
\hline \multirow[b]{2}{*}{ Test bacteria } & \multicolumn{3}{|c|}{$\begin{array}{l}\text { Aspillia africana } \\
(100 \mathrm{mg} / \mathrm{ml})\end{array}$} & \multicolumn{3}{|c|}{$\begin{array}{l}\text { Psidium guajava } \\
\quad(100 \mathrm{mg} / \mathrm{ml})\end{array}$} \\
\hline & $\mathrm{A}$ & $\mathrm{E}$ & M & A & $\mathrm{E}$ & M \\
\hline Providencia stuartii & - & 12 & 4 & 8 & 12 & 4 \\
\hline Bacillus cereus & - & - & - & - & - & - \\
\hline Staphylococcus aureus & 15 & 16 & 3 & 7 & 12 & 15 \\
\hline Corynebacterium pyogenes & - & - & - & - & - & - \\
\hline Streptococcus faecalis & 4 & 8 & - & & 15 & 4 \\
\hline Klebsiella oxytoca & - & - & - & - & - & - \\
\hline Klebsiella pneumonia & - & - & - & - & - & - \\
\hline Escherichia coli & - & - & - & - & - & - \\
\hline Pseudomonas fluorescens & 8 & 10 & - & - & - & - \\
\hline Serratia rubidae & - & - & - & 4 & 7 & - \\
\hline Proteus mirabilis & - & - & - & - & - & - \\
\hline $\begin{array}{l}\text { Salmonella pullorum } \\
\text { Test fungi }\end{array}$ & - & - & - & - & - & - \\
\hline Trychophyton tonsurans & 1 & 2 & - & - & - & - \\
\hline Candida albicans & - & - & 1 & - & - & - \\
\hline Trychophyton rubrum & - & - & - & - & - & - \\
\hline Penicillium expansium & - & - & - & - & - & - \\
\hline Alternaria sp. & - & - & - & - & - & - \\
\hline Fusarium sp. & 3 & 5 & 2 & - & - & - \\
\hline Aspergillus niger & - & - & - & - & - & - \\
\hline Aspergillus fumigates & - & - & - & - & - & - \\
\hline Aspergillus flavus & - & - & - & - & - & - \\
\hline Penicillium camenberti & - & - & - & - & - & - \\
\hline
\end{tabular}

CLSI. Performance standards for antimicrobial susceptibility testing. Clinical and laboratory standards institute, $29^{\text {th }}$ ed, 2019.

medicinally and pharmaceutically important plants to health care cannot be over-emphasized. There is a growing demand to discourage the usage of drugs with high clinical toxicity. However, the usual practice of oral administration of crude extracts poses threat to human health as the extracts may contain some toxic components ${ }^{5}$. These ambivalent challenges had necessitated the search for antibiotics in institutions, industries and the academic community ${ }^{6}$. Plants have major advantage over synthetic drugs because it's cost effective, readily available, cheaper alternative and pharmacological importance ${ }^{7}$. Several studies have been reported on the antibacterial activities of local plants such as Euphorbia hirta, Kigelia Africana, Hibiscus sabdarifa and Mucuna pruriens ${ }^{8}$.

Aspillia africana (Compositae) is a tropical shrub, semi-woody herb from a perennial root widely grown in Nigeria where it is commonly known as Yunrinyun by the Yorubas, Orangila by Igbos and Tozalin by Hausas. The plant is about $2 \mathrm{~m}$ high, polymorphic and ubiquitous on western land of Savannah. Its formulations had been used in the treatment of various bacterial infections such as gastro-intestinal disorders, corneal opacity and insect
Psidium guajava L. (Mytaceae) is one of such plants in folk medicine that had been extensively used for the treatment of various disease conditions like fever, dysentery, vomiting and inflamed gums ${ }^{10}$. The extract from the leaves were found to display analgesic and antiinflammatory potntial ${ }^{11}$, antimicrobial and antioxidant activities $^{12}$. The alarming increase of resistance to antibiotics by microorganisms cannot be overemphasized. This had necessitated scientist to search for alternative strategies of mitigating this challenge. The objectives of the study are therefore to investigate the antimicrobial potential of the leaves of Aspillia africana and Psidium guajava plants on some selected bacterial and fungal isolates; and to investigate the synergistic antimicrobial effects of the extracts on the test organisms.

\section{Materials and methods \\ Preparation and authentication of plant samples}

A vey fresh and matured leaves of Aspillia africana and Psidium guajava were collected at the Federal College of Agriculture, Akure and Botanical Garden, Obafemi Awolowo University (OAU), Ile-Ife, Nigeria. The specimens were identified at IFE Herbarium, 
Department of Botany, Obafemi Awolowo University, Ile-Ife and voucher deposited. Each plant sample was separately washed and rinsed several times in distilled water. The samples were dried to constant weight in an oven and ground into powdery form using laboratory blender. The powder $(100 \mathrm{~g})$ obtained were extracted with $500 \mathrm{ml}$ of sterile distilled water, $500 \mathrm{ml}$ ethanol and $500 \mathrm{ml}$ methanol by soaking in water for 5 days and then filtered. The filtrates were later concentrated at $45^{\circ} \mathrm{C}$ using a motorized rotary evaporator (Resona England). The dried samples were kept in sterile bottles for future use.

Table 2. Synergistic antibacterial and antifungal effects of the plant extracts on the tested microorganisms

\begin{tabular}{c}
\hline $\begin{array}{c}\text { Aspillia africanat } \\
\text { Psidium guajava }\end{array}$ \\
\hline A $\mathrm{E} \mathrm{M} ~ \mathrm{M}$ \\
$(100 \mathrm{mg} / \mathrm{ml})$ \\
\hline
\end{tabular}

\begin{tabular}{|c|c|c|c|}
\hline \\
\hline $\begin{array}{l}\text { Test bacteria } \\
\text { Providencia stuartii }\end{array}$ & 6 & 18 & 15 \\
\hline Bacillus cereus & $\begin{array}{l}2 \\
2\end{array}$ & 4 & 3 \\
\hline $\begin{array}{l}\text { Staphylococcus aureus } \\
\text { Corynebacterium }\end{array}$ & 0 & 21 & 7 \\
\hline pyogenes & $\begin{array}{l}1 \\
1\end{array}$ & 1 & 2 \\
\hline Streptococcus faecalis & 6 & 12 & 6 \\
\hline Klebsiella oxytoca & 4 & 8 & 2 \\
\hline Klebsiella pneumonia & - & - & - \\
\hline Escherichia coli & - & - & - \\
\hline Pseudomonas fluorescens & 1 & 1 & 6 \\
\hline Serratia rubidae & 6 & 6 & 1.2 \\
\hline Proteus mirabilis & - & - & - \\
\hline Salmonella pullorum & - & - & - \\
\hline \multicolumn{4}{|l|}{ Test fungi } \\
\hline Trychophyton tonsurans & - & - & - \\
\hline Candida albicans & - & - & - \\
\hline Trychophyton rubrum & - & - & - \\
\hline Penicillium expansium & - & - & - \\
\hline Alternaria sp. & - & - & - \\
\hline Fusarium sp. & 2 & 4 & 2 \\
\hline Aspergillus niger & - & - & - \\
\hline Aspergillus fumigatus & - & - & - \\
\hline Aspergillus flavus & - & - & - \\
\hline Penicillium carmenberti & - & - & - \\
\hline
\end{tabular}

KEY: A - Aqueous extracts, E - Ethanolic extracts, M - Methanolic extract

CLSI. Performance standards for antimicrobial susceptibility testing. Clinical and laboratory standards institute, $29^{\text {th }}$ ed, 2019.

\section{Preparation of test organism}

The pure isolates of the bacteria and fungi used in this research were obtained from Medical Microbiology unit, Department of Microbiology, Obafemi Awolowo
University, Ile-Ife, Nigeria. The bacteria isolates were maintained on nutrient broth and the fungal isolates on SDA. The isolates were constantly sub cultured at fourteen days interval. Before use, the isolates were inoculated into separate test tube that was plugged with adsorbent containing $10 \mathrm{ml}$ Mueller- Hinton broth which were incubated for $24 \mathrm{~h}$ at $37^{\circ} \mathrm{C}$. The test organisms include bacteria namely, Providencia stuartii, Bacillus cereus, Staphylococcus aureus, Corynebacterium Pyogenes, Streptococcus faecalis, Klebsiella oxytoca, Klebsiella pneumoniae, Escherichia coli, Pseudomonas flourescens, Serratia rubidae, Proteus mirabilis, Salmonella pullorum; and fungi namely, Trychophyton tonsurans, Candidia albicans, Trychophyton rubrum, Penicillium expansium, Alternaria sp, Fusarium sp, Aspergillus niger, Aspergillus fumigatus, Aspergillus flavus, and Penicillium camenberti.

\section{Preparation and Extraction of Plant Materials}

Freshly harvested sampled leaves of $A$. africana and $P$. guajava were thoroughly washed with distilled and rinsed accordingly. Twenty gram each of the leaves was weighed on an electric weighing balance for methanol, ethanol and aqueous extraction. The leaves $(20 \mathrm{~g})$ were later grounded with mortar and pestle and then transferred into labeled petridishes. Incubation was carried out at $37^{\circ} \mathrm{C}$ for $24 \mathrm{~h}$. About $90 \mathrm{ml}$ each of the solvent were added to the grounded leaves for extraction, vigorously shaken for 30 minutes and allowed to settle.

Sensitivity Test: Antibacterial and Antifungal assay was carried out following established protocols.

\section{Preparation of the medium}

$40 \mathrm{~g}$ of Mueller-Hinton agar powder were carefully weighed into a clean conical Flask and $100 \mathrm{ml}$ of sterilized distilled water was dispensed into the conical flask to achieve homogeneity using magnetic stirrer before autoclaving at $121^{\circ} \mathrm{C}$ for $15 \mathrm{~min}$. The plates were allowed to cool for $2 \mathrm{~h}$ before a cork borer (No 4) was flamed and used to bore wells $(6 \mathrm{~mm})$. The plant extracts were filled into the wells and labelled appropriately.

\section{Inoculation of medium}

Inoculation of the medium was achieved using spread plate method. The fungal isolates selected were allowed to colonize the Sabouraud Dextrose Agar (SDA) at $25^{\circ} \mathrm{C}$ until after sporulation. The fungal spores were harvested by pouring a mixture of sterile glycerol and distilled water (3:100 i.e $3 \%$ glycerol) to the surface of the plate and later the spores were scraped. The harvested fungal spores were standardized before use. The plates were allowed to cool on the laboratory bench for one hour to allow for homogenous diffusion of the extract into the media. Plates were incubated at $25^{\circ} \mathrm{C}$ for 96 hours and later observed for zones of inhibition.

\section{Minimal inhibitory concentration (MIC)}

The minimum inhibitory concentration (MIC) of the extracts was determined following established protocols. About $100 \mathrm{mg} / \mathrm{ml}$ of the extracts were prepared and introduced into the test tubes containing $8 \mathrm{ml}$ of sterile Mueller-Hinton broth, $1 \mathrm{ml}$ of the different extract concentration and $1 \mathrm{ml}$ broth culture. The mixture was homogenized and then incubated at $37^{\circ} \mathrm{C}$ for $24 \mathrm{~h}$. The 
estimation of minimal inhibitory concentration of the plant extracts on the fungi was determined using established protocols. Plant extracts was prepared and $2 \mathrm{ml}$ of different concentrations of the solution were added to Sabouraud Dextrose Agar (SDA) at $40^{\circ} \mathrm{C}$ to give the appropriate concentration. The medium was then poured to sterile Petri-dishes and allowed to cool. The extracts were then streaked with fungal spores The plates were incubated at $25^{\circ} \mathrm{C}$ for 5 days and were examined for the presence or absence of fungal growth. The MIC was taking as the lowest concentration that inhibited the growth of the test fungi.

\section{Minimal bactericidal and fungicidal concentration (MBC and MFC)}

Minimal bactericidal concentration (MBC) was determined by plating $1 \mathrm{ml}$ of the MIC positive tubes on nutrient agar to ascertain the bactericidal effect of the extracts. Samples were taken from plates with no significant growth in the MIC culture and sub-cultured on freshly prepared Mueller-Hinton agar plates for determination of MBC and SDA plates for MFC and later incubated at $25^{\circ} \mathrm{C}$ for 5 days.

\section{Synergistic antimicrobial effects of the plant extracts against tested bacterial and fungal isolates:}

The synergistic antimicrobial effects of the various combinations of the plant extracts for the test microorganisms were determined using the method employed by ${ }^{14}$. To demonstrate synergism, equal quantity of plant combinations were weighed and dissolved in the appropriate quantity of the dilution to give the $100 \mathrm{mg} / \mathrm{ml}$ concentrations which was used for the antimicrobial test ${ }^{13}$. Antimicrobial susceptibility testing will be compared with clinical and laboratory standard institute (CLSI, 2019) ${ }^{15}$.

\section{Results}

Antimicrobial effect of methanolic (M), Ethanolic (E) and Aqueous (A) extracts of Aspillia africana and Psidium guajava on some selected bacterial and fungal isolates

The zones of inhibition of the extracts ranged from $1-15 \mathrm{~mm}$ for bacteria while fungal isolates ranged between 1 and $7 \mathrm{~mm}$ respectively. The highest and lowest zones of inhibition of $15 \mathrm{~mm}$ and $3 \mathrm{~mm}$ respectively were obtained in Staphyloccocus aureus under the aqueous and methanolic fractions. Bacillus cereus, Cornybacterium pyogenes, Klebsiella pneumonia and Escherichia coli showed high degree of resistance to the plant extracts. The fungal isolates; Candida albicans, Tryptophyton rubrum, Penicillium expansium, and Aspergillus flavus were resistant to Psidium guajava extract as no significant activity was observed. There were no significant effect of the plant extracts against tested fungi isolates (Table 1).

\section{Synergistic antibacterial and antifungal effects of the} plant extracts on the tested microorganisms.

The fungal isolates were resistant to the plant extracts as no significant effect was observed. However, the highest zone of inhibition of $21 \mathrm{~mm}$ was observed in $S$. aureus under the ethanolic fraction while the lowest $(1.2 \mathrm{~mm})$ was noticeable in Serratia rubidae under the methanolic extract (Table 2). Escherichia coli and Klebsiella pneumonia were both resistant to the synergistic effect of the plant extracts.

Susceptibility of the test organisms to reference drugs

The susceptibility of the test organisms to antibiotics and antifungal drug is presented in Table 3. Some of the micoorganisms which were sensitive to the plant extracts were found to be resistant to some of the antibiotics used. All the plant extracts produced considerable antimicrobial activities with Streptococcus faecalis and S. aureus, whereas, these organisms were resistant to ofloxacin, sparfloxacin, chloramphenicol, augmentin, ciprofloxacin and septrin. (Table 3). However, the antifungal drug (Ketoconazole) was more effective on the test fungi than the plant extracts.

Minimum inhibitory concentrations (MICs) of the plant extracts against the tested micoorganims

The MIC ranged from 25 to $250 \mu \mathrm{g} / \mathrm{ml}$. The lowest MIC $(25 \mu \mathrm{g} / \mathrm{ml})$ was recorded against $P$. stuartii with ethanolic extract of $P$. guajava. Also, the aqueous and ethanolic extracts of $P$. guajava and had a MIC of $25 \mu \mathrm{g} / \mathrm{ml}$ on $S$. aureus. The highest MIC $(250 \mu \mathrm{g} / \mathrm{ml})$ was recorded with the aqueous extract of $A$. africana against $P$. fluorescence, and methanolic extracts of $P$. guajava on $S$. faecalis (Table 4). The MIC of the plant extracts against selected fungi ranged from $150-300 \mu \mathrm{g} / \mathrm{ml}$. Aqueous and ethanolic extracts of A. africana recorded MIC of $250 \mu \mathrm{g} / \mathrm{ml}$ on $T$. tonsurans and Fusarium sp. respectively. The highest MIC $(300 \mu \mathrm{g} / \mathrm{ml})$ was obtained with methanolic extract of $A$. africana on Fusarium sp (Table 4).

Minimum bactericidal concentrations (MBCs) of the plant extracts against the tested organisms

The MBC ranged from $50-400 \mu \mathrm{g} / \mathrm{ml}$. The lowest MBC $(50 \mu \mathrm{g} / \mathrm{ml})$ was obtained with ethanolic and aqueous extracts of $P$. guajava against $S$. aureus. The highest MBC $(400 \mu \mathrm{g} / \mathrm{ml})$ was obtained with the aqueous and ethanolic extracts of A. africana, and methanolic extract of $P$. guajava on $S$. faecalis respectively (Table 5).

\section{Discussion}

Nigeria is repleted with reservoir of medicinal plants. The economic burden and health implications of antimicrobial resistance are quite alarming. The unquantifiable extent of the antimicrobial potency of plant extracts orchestrated by characterization of abundant secondary metabolites inherent in these plants necessitated research on traditional medicine. Findings from this study revealed that aqueous and ethanolic extracts of the leaf of Aspillia africana is more potent than the extracts of Psidium guajava. A. Africana posess antibacterial activity against Staphylococcus aureus, Streptococcus feacalis and Pseudomonas fluorescens. ${ }^{16}$ reported earlier that the ethanolic extract of the leaf of A. africana posess antibacterial potentials against these microorganisms. However, Psidium guajava exhibited no antimicrobial activity against the tested fungal isolates. Among the bacterial isolates Stapylococcus aureus were the most sensitive to the plant extracts while 


\begin{tabular}{|c|c|c|c|c|c|c|c|c|c|c|c|c|c|c|c|c|}
\hline \multirow{2}{*}{$\frac{\text { Test Bacteria }}{\text { Gram negative }}$} & \multicolumn{16}{|c|}{$\begin{array}{c}\text { Diameter of Zones of Inhibition } \\
(\mu \mathrm{g})\end{array}$} \\
\hline & $\begin{array}{r}\text { OFL } \\
(5) \\
\end{array}$ & $\begin{array}{l}\text { SP } \\
(\mathbf{1 0})\end{array}$ & $\begin{array}{l}\text { CHL } \\
(30)\end{array}$ & $\begin{array}{l}\text { AUG } \\
(30)\end{array}$ & $\begin{array}{l}\text { CPX } \\
(5)\end{array}$ & $\begin{array}{l}\text { SXP } \\
(5)\end{array}$ & $\begin{array}{l}\text { AMX } \\
(25)\end{array}$ & $\begin{array}{l}\text { GEN } \\
(10)\end{array}$ & $\begin{array}{l}\text { PEF } \\
(5)\end{array}$ & $\begin{array}{l}\text { STR } \\
(10)\end{array}$ & $\begin{array}{l}\text { APX } \\
(10)\end{array}$ & $\begin{array}{l}\mathbf{Z} \\
() \\
\end{array}$ & $\begin{array}{c}\text { CT } \\
(30)\end{array}$ & $\begin{array}{r}\text { ERY } \\
(10) \\
\end{array}$ & $\begin{array}{l}\mathbf{N} \\
()\end{array}$ & $\begin{array}{l}\mathbf{C M} \\
()\end{array}$ \\
\hline Escherichia coli & $15(\mathrm{R})$ & $17(\mathrm{R})$ & $14(\mathrm{R})$ & $13(\mathrm{R})$ & $18(\mathrm{~S})$ & $13(\mathrm{R})$ & $13(\mathrm{R})$ & $16(\mathrm{~S})$ & $17(\mathrm{~S})$ & $14(\mathrm{R})$ & - & - & - & - & - & - \\
\hline Klebsiella pneumoniae & $0(\mathrm{R})$ & $0(\mathrm{R})$ & $15(\mathrm{~S})$ & $20(\mathrm{~S})$ & $0(\mathrm{R})$ & $12(\mathrm{R})$ & $16(\mathrm{R})$ & $12(\mathrm{R})$ & $23(\mathrm{~S})$ & $0 \quad(\mathrm{R})$ & - & - & - & - & - & - \\
\hline Klebsiella oxytoca & $0(\mathrm{R})$ & $16(\mathrm{R})$ & $20(\mathrm{~S})$ & $16(\mathrm{R})$ & $18(\mathrm{~S})$ & $22(\mathrm{~S})$ & $16(\mathrm{R})$ & $14(\mathrm{R})$ & $20(\mathrm{~S})$ & $18(\mathrm{~S})$ & - & - & - & - & - & - \\
\hline Pseudomonas fluorescens & $0(\mathrm{R})$ & $13(\mathrm{R})$ & $20(\mathrm{~S})$ & $12(\mathrm{R})$ & $18(\mathrm{~S})$ & $14(\mathrm{R})$ & $20(\mathrm{R})$ & $16(S)$ & $12(\mathrm{R})$ & $20(\mathrm{~S})$ & - & - & - & - & - & - \\
\hline Serratia rubidae & $4(\mathrm{R})$ & $4(\mathrm{R})$ & $5(\mathrm{R})$ & $0(\mathrm{R})$ & $12(\mathrm{R})$ & $0(\mathrm{R})$ & $0(\mathrm{R})$ & $8(\mathrm{R})$ & $16(S)$ & $12(\mathrm{R})$ & - & - & - & - & - & - \\
\hline Proteus mirabilis & $8(\mathrm{R})$ & $6(\mathrm{R})$ & $2(\mathrm{R})$ & $0(\mathrm{R})$ & $16(\mathrm{R})$ & $20(\mathrm{~S})$ & $4(\mathrm{R})$ & $22(\mathrm{~S})$ & $16(S)$ & $2(\mathrm{R})$ & - & - & - & - & - & - \\
\hline Salmonella pullorum & $19(\mathrm{~S})$ & $0(\mathrm{R})$ & $2(\mathrm{R})$ & $0(\mathrm{R})$ & $0(\mathrm{R})$ & $16(\mathrm{~S})$ & $0(\mathrm{R})$ & $21(\mathrm{~S})$ & $22(\mathrm{~S})$ & $0 \quad(\mathrm{R})$ & - & - & - & - & - & - \\
\hline Providential stuartii & $4(\mathrm{R})$ & $4(\mathrm{R})$ & $5(\mathrm{R})$ & $0(\mathrm{R})$ & $12(\mathrm{R})$ & $0(\mathrm{R})$ & $0(\mathrm{R})$ & $8(\mathrm{R})$ & $16(S)$ & $12(\mathrm{R})$ & - & - & - & - & - & - \\
\hline Bacillus cereus & - & - & - & - & - & - & $0(\mathrm{R})$ & $24(\mathrm{~S})$ & $26(S)$ & $20(\mathrm{~S})$ & $0(\mathrm{R})$ & $24(\mathrm{~S})$ & $0(\mathrm{R})$ & $4(\mathrm{R})$ & $8(\mathrm{R})$ & $10(\mathrm{R})$ \\
\hline $\begin{array}{l}\text { Staphlococcus aureus } \\
\text { Corynebacterium }\end{array}$ & - & - & - & - & - & - & $0(\mathrm{R})$ & $22(\mathrm{~S})$ & $18(\mathrm{~S})$ & $0 \quad(\mathrm{R})$ & $0 \quad(\mathrm{R})$ & $0(\mathrm{R})$ & $0(\mathrm{R})$ & $0(\mathrm{R})$ & $19(\mathrm{~S})$ & $0 \quad(\mathrm{R})$ \\
\hline pyogenes & - & - & - & - & - & - & $12(\mathrm{R})$ & $3(\mathrm{R})$ & $21(\mathrm{~S})$ & $0 \quad(\mathrm{R})$ & $19(\mathrm{~S})$ & $12(\mathrm{R})$ & $4(\mathrm{R})$ & $10(\mathrm{R})$ & $19(\mathrm{~S})$ & $0 \quad(\mathrm{R})$ \\
\hline Streptococcus faecalis & - & - & - & - & - & - & $12(\mathrm{R})$ & $17(\mathrm{~S})$ & $7(\mathrm{R})$ & $0 \quad(\mathrm{R})$ & $8(\mathrm{R})$ & $10(\mathrm{R})$ & $10(\mathrm{R})$ & $15(\mathrm{~S})$ & $6(\mathrm{R})$ & $0 \quad(\mathrm{R})$ \\
\hline Test Fungi & \multicolumn{16}{|c|}{ Concentrations of Ketofung (mg/ml) } \\
\hline & 05 & 10 & 20 & & & & & & & & & & & & & \\
\hline Trychophyton tonsurans & 18 & 34 & 37 & & & & & & & & & & & & & \\
\hline Candida albicans & 18 & 25 & 33 & & & & & & & & & & & & & \\
\hline Penicillium expansium & 16 & 22 & 28 & & & & & & & & & & & & & \\
\hline Alternaria sp. & 11 & 13 & 17 & & & & & & & & & & & & & \\
\hline Fusarium sp. & 21 & 26 & 32 & & & & & & & & & & & & & \\
\hline Aspergillus niger & 16 & 18 & 24 & & & & & & & & & & & & & \\
\hline Aspergillus fumigates & 18 & 25 & 30 & & & & & & & & & & & & & \\
\hline Aspergillus flavus & 20 & 22 & 28 & & & & & & & & & & & & & \\
\hline Penicillum camenberti & 14 & 18 & 22 & & & & & & & & & & & & & \\
\hline Trychophyton rubrum & 17 & 22 & 27 & & & & & & & & & & & & & \\
\hline
\end{tabular}

OFL= ofloxacin $(5 \mu \mathrm{g}), \mathrm{SP}=$ Sparfloxacin $(5 \mu \mathrm{g}), \mathrm{CHL}=$ Chloramphenicol $(30 \mu \mathrm{g}), \mathrm{AUG}=$ Augmentin $(30 \mu \mathrm{g}), \mathrm{CPX}=$ Ciprofloxacin $(5 \mu \mathrm{g}), \mathrm{SXP}=\mathrm{Septrin}(25 \mu \mathrm{g}), \mathrm{AMX}=\mathrm{Amoxicillin}(25 \mu \mathrm{g}), \mathrm{GEN}=\mathrm{Gentamycin}(10 \mu \mathrm{g}), \mathrm{PEF}=\mathrm{Pefloxacin}$ $(5 \mu \mathrm{g}), \mathrm{STR}=$ Streptomycin $(10 \mu \mathrm{g}), \mathrm{APX}=$ Ampiclox $(10 \mu \mathrm{g}), \mathbf{Z}=$ Zinnacef $(\boldsymbol{\mu g}), \mathrm{CT}=$ Ceftriazone $(30 \mu \mathrm{g}), \mathrm{ERY}=$ Erythromycin $(10 \mu \mathrm{g}), \mathbf{N}=\mathbf{N i t r o f u r a n t o i n}(\boldsymbol{\mu g}), \mathbf{C M}=\mathbf{C l a r i t h o m y c i n}(\boldsymbol{\mu} \mathrm{g})$ 
Corynebacterium pyogens and Escherichia coli were the most resistant. The prolific synergistic sensitivity of the test isolates to aqueous and ethanolic extracts of both plants is at variance with the findings of ${ }^{17}$, who reported that ethanol as the best solvent for the extraction of bioactive components from plants. This study showed that $A$. africana extract was active on both Gram-negative (P. fluorescence and P. stuartii) and Gram-positive (S. aureus and S. faecalis) bacterial at $100 \mathrm{mg} / \mathrm{ml}$. Similar findings were reported by ${ }^{18}$ on the evaluation of aqueous extracts of the leaves of $A$. Africana in Sierra Leone which exhibited antibacterial activities on both Gram-positive and Gram-negative organisms at concentrations which ranged from 0.1 $0.5 \mathrm{~g} / \mathrm{ml}$. However, the present study contradicts the findings of ${ }^{17}$ who reported aqueous extract of $A$. africana to be active on E. coli and Salmonella sp at concentrations ranging from $0.1-0.5 \mathrm{~g} / \mathrm{ml}$. In the present study, the extract of $P s$. guajava exhibited inhibitory property on $S$. aureus, $S$. faecalis and $P$. Stuartii thus conforms to earlier reports by ${ }^{19-20}$ and $^{21}$ who reported the antibacterial activity of Ps. guajava leaf. ${ }^{20}$ also reported the efficacy of the plant extract in the treatment of diarrhoea, dysentery and wounds. Most of the microorganisms tested in this study have been implicated in various gastrointestinal infections such as watery diarrhoea, nausea, vomiting, abdominal pain, pediatric diarrhoea, typical gastroenteritis, necrotizing enterocolitis and/or dysentery ( $E$. coli, Klebsiella sp. and Salmonella sp) and wound infection (Staphylococcus sp., Streptococcus sp., Proteus sp. and Pseudomonas sp). The synergistic antimicrobial effect of the various plants extracts showed that the zones of inhibition increased considerably compared to when extracts were used singly. The wider zones of inhibition recorded may be due to resultant effects of the bioactive compounds in the extracts. ${ }^{21}$ reported in their studies on in vitro synergistic activities of some herbs on $S$. typhi, that antimicrobial activity of some plants extracts increase when used synergistically. However, E. coli, P. mirabilis, P. expansium, Alternaria spp, A. fumigatus, A. flavus and $P$. carmenberti all displayed resistance to all the combined extracts tested. This may be due to the possibility that the active ingredient of one particular plant may not be complementary to another, thereby resulting in neutralization or denaturalisation of the plants components. The results obtained from the minimum inhibitory concentration (MIC) of the various plants extracts showed that the plant extracts are very potent against the pathogens at the MIC of $25 \mu \mathrm{g} / \mathrm{ml}$. The high MIC obtained on the test fungi confirmed their low susceptibility to virtually all the extracts tested. The MICs of the fungal isolates ranged between 150 and $300 \mu \mathrm{g} / \mathrm{ml}$. The low susceptibility of these fungi to these extracts may likely be attributed to the fact that majority of fungi interact with plants in the field and would have naturally developed resistance to the active antimicrobial ingredients in these plants.

\section{CONCLUSION}

This study concludes that ethanolic extracts $(100 \mathrm{mg} / \mathrm{ml})$ of the leaf of Aspillia africana is more potent than the methanolic and aqueous extracts of Psidium guajava. The plant extracts showed greater antimicrobial activity on the bacterial isolates than on the fungal isolates suggesting a broader spectrum of activity with ethanolic extract on the gram positive and the gram negative bacteria. The therapeutic properties of Aspillia africana and Psidium guajava is better enhanced with their synergistic potential to the tested microorganisms.

Table 4. Minimum inhibitory concentrations (MICs) of the plant extracts against the tested microorganisms

\begin{tabular}{lcccccc} 
& \multicolumn{3}{c}{ Aspillia } & & \multicolumn{3}{c}{ Psidium } \\
africana & \multicolumn{3}{c}{ guajava } \\
Test Bacteria & A & E & M & A & E \\
\hline Providencia stuartii & - & 50 & M & A & E \\
Bacillus cereus & - & - & 50 & 50 & 25 \\
Staphylococcus aureus & 50 & 50 & 100 & - & - \\
Streptococcus faecalis & 200 & 200 & 100 & 25 & 25 \\
Klebsiella oxytoca & - & - & - & 100 & 100 \\
Klebsiella pneumonia & - & - & 100 & - & - \\
Escherichia coli & - & - & 200 & - & - \\
Pseudomonas fluorescence & 250 & 200 & - & - & - \\
Salmonella pullorum & - & - & 250 & - & - \\
Corynebacterium pyogenes & - & - & - & - & - \\
Serratia rubidae & - & - & - & - & - \\
Test Fungi & & & - & 150 & 150 \\
Trychophyton tonsurans & 250 & 250 & & & \\
Candida albicans & 250 & - & - & - & - \\
Trychophyton rubrum & - & - & - & - & - \\
Fusarium H. & 250 & 250 & - & - & - \\
Aspergillus niger & - & - & 250 & - & - \\
\hline KEY: A Aqu & & - &
\end{tabular}

KEY: A - Aqueous extracts, $\mathrm{E}-$ Ethanolic extracts, $\mathrm{M}-$ Methanolic extract

CLSI. Performance standards for antimicrobial susceptibility testing. Clinical and laboratory standards institute, $29^{\text {th }} \mathrm{ed}$, 2019.

Table 5. Minimum bactericidal concentrations (MBCs) of the plant extracts against tested microorganisms

\begin{tabular}{lccccc}
\multicolumn{2}{l}{ extracts against tested microorganisms } & & & \multicolumn{2}{r}{$\begin{array}{c}\text { Psdium } \\
\text { guajava }\end{array}$} \\
Test Bacteria & A & E & M & A & E \\
Providencia stuartii & - & 150 & 150 & 100 & 50 \\
Bacillus cereus & - & - & 300 & - & - \\
Staphylococcus aureus & 150 & 150 & 300 & 50 & 50 \\
Streptococcus faecalis & 400 & 400 & - & 250 & 200 \\
Klebsiella oxytoca & - & - & 200 & - & - \\
Klebsiella pneumonia & - & - & 400 & - & - \\
Escherichia coli & - & - & - & - & - \\
Pseudomonas fluorescence & 400 & 300 & 400 & - & - \\
Salmonella pullorum & - & - & - & - & - \\
Corynebacterium pyogenes & - & - & - & - & - \\
Serratia rubidae & - & - & - & 200 & 250 \\
\hline
\end{tabular}

\section{RECOMMENDATION}

A further study on the proper formulation into drugs of the plant extracts for human consumption is highly 
recommended. The toxicological studies of the extracts on experimental animals should be determined in order to ascertain its safety threshold on humans.

\section{ACKNOWLEDGEMENT}

The authors appreciate the efforts of the Technical Staff of the Department of Microbiology, Obafemi Awolowo University, Ile-Ife, Nigeria and the Federal College of Agriculture, Akure. The authors also thanked the Herbarium unit of the Department of Botany, Obafemi Awolowo University, Ile-Ife for providing the passport information for the specimen and voucher subsequently deposited.

\section{REFERENCES}

1. Ivanišová, E. Tokár, M. Mocko, K. Bojňanská, T. Mareček, J. and Mendelova. Antioxidant activity of selected plant products, Journal of microbiology, biotechnology and food science; 2010, 2: 1692-1703.

2. World Health Organization. Review of Summary of WHO guidelines for the assessment of herbal medicine. Herbal Gram; 2013; 28: 13-14.

3. Okeke MI, Iroegbu CU, Eze EN, Esimone CO. Evaluation of extracts of the root of Landolphia owerrience for antibacterial activity. Journal of Ethnopharmacology; 2011; 78: 119-127..

4. Ologundudu FA, Obimakinde ET, Osunyemi OS, Akinnifesi OJ. Antimicrobial activity and phytochemical screening of leaf and bark of Blighia sapida. Journal of genetics and cell biology; 2018; 2(1): 36-43.

5. Salau, A.O. and Odeleye, O.M. Antimicrobial activity of Mucuna pruriens on selected bacteria. African Journal of Biotechnology; 2007; 6(18): 2091-2092.

6. Jyothi, MJ, AVS-Praveen KA, Mohanalakshmi GKR, Prathyusha S. A review on anti-ulcer medicinal plants. International Journal of Pharmacology and Toxicology; 2012; 2(2): 95103.

7. Ojewole TF. In Vitro antimicrobial activity of Zingiber cassumunar (Plai) oil and a 5\% oil gel. Phytotherapy Research; 2016; 21: 164-169.

8. Ray KH, Kuscu A, Ozcan M. Effect of Turkish spice extracts at various concentrations on growth of E. coli. Food Protection; 2012; 19: 473-480.

9. Nair AC, and Chandra T. Molecular epidemiology of multidrug resistant extended spectrum betalactamase producing Klebsiella pneumoniae at a Jamaican hospital, 2000-2004. BMC Microbiology; 2017; 141: 174-177.
10. Igbinosa OO, Igbinosa EO, Aiyegoro OA. Antimicrobial activity and phytochemical screening of stem bark extracts from Jatropha curcas (Linn). African Journal of Pharmacy and Pharmacology; 2009; 3(2): 58-62.

11. Junaid SA, Olabode AO, Onwuliri FC, Okwori AE, Agina SE. The antimicrobial properties of Ocimum gratissimum extracts on some selected bacterial gastrointestinal isolates. African Journal of Biotechnology; 2006; 5(22): 2315-2321.

12. Abioye, E.O. Akinpelu, D.A. Aiyegoro, O.A. Adegboye, M.F. Oni, M.O. Okoh, A.I. Preliminary phytochemical screening and antibacterial properties of crude stem bark extracts and fractions of Parkia biglobosa (Jacq.). 2013, Molecules. 18: 8485-8499

13. Oluduro AO, and Omoboye OO. In vitro antibacterial potentials and synergistic effects of South-Western Nigerian plants parts used in folklore remedy for Salmonella typhi infection. Nature and Science; 2010; 8(9): 52-59.

14. Anibijuwon II, Duyilemi, OP. Antimicrobial activity of the leaf of Aspillia africana of some pathogenic organisms of clinical origin. Nigerian journal of microbiology; 2010; 24(1): 2048-2055.

15. CLSI. Performance standards for antimicrobial susceptibility testing. Clinical and laboratory standards institute, 29th ed, 2019.

16. Obi VF, and Onouha CI. Extraction and characterization methods of plants and plant products. Biological and Agricultural techniques; 2017; Webmedia publishers, Owerri, 271-286.

17. Ubaka MC, Ukwe VC, Okoye CT, Adibe OM. Investigation into the Anti-ulcer Activity of the Aqueous Leaf Extract of Aspilia africana. Asian Journal of Medical Sciences, 2010; 2(2): 40-43.

18. Rebecca N, John DK. Antibacterial activity and phytochemical screening of eleven plants used as poultry ethno-medicines in Southern Uganda. Agricultural Journal; 2011; 6(6):303-309.

19. Adaramola, T.F. Ariwaodo, J.O. and Adeniji, K.A. Distribution, Phytochemistry and Antioxidant Properties of the Genus Parkia R.br. (Mimosaceae) in Nigeria. International Journal of Pharmacognosy and Phytochemical Research, 2012, 4: 172-178.

20. Geidam S, Prasad BN, Lakshmi V. Antiamoebic activity of Piper longum fruits against Entamoeba histolytica in vitro and in vivo. Journal Ethnopharmacology; 2007; 50: 167-170.

21. Sushimita C, Langer C, Beubler E. Klebsiella oxytoca as a causative organism of antibiotic associated hemorrhagic clotis. New England Journal of Medicine; 2012; 355(23): 2418-2426 